Article

\title{
Synthesis of Complex-Alloyed Nickel Aluminides from Oxide Compounds by Aluminothermic Method
}

\author{
Victor Gostishchev ${ }^{1}$, Ernst $\mathrm{Ri}^{2}$, Hosen $\mathrm{Ri}^{2}$, Evgeniy Kim ${ }^{2}$, Michail Ermakov ${ }^{2}$, \\ Sergey Khimukhin ${ }^{1}$, Vladislav Deev ${ }^{3,4}$ and Evgeny Prusov ${ }^{5, *}$
}

1 Institute for Materials Technology, Khabarovsk Research Centre at the Far Eastern Branch of the Russian Academy of Sciences, Tihookeanskaya Str. 153, 680042 Khabarovsk, Russia; v-gostishev@mail.ru (V.G.); ximyxin@yandex.ru (S.K.)

2 Department of Foundry Engineering and Metal Technology, Pacific National University, Tihookeanskaya Str. 136, 680042 Khabarovsk, Russia; erikri999@mail.ru (E.R.); opirus@bk.ru (H.R.); ri@mail.khstu.ru (E.K.); equalgod88@gmail.com (M.E.)

3 Department of Foundry Technology, National University of Science \& Technology MISIS, Leninsky Pr. 4, 119049 Moscow, Russia; deev.vb@mail.ru

4 School of Mechanical Engineering and Automation, Wuhan Textile University, 1 FangZhi Road, Wuhan 430073, China

5 Department of Functional and Constructional Materials Technology, Vladimir State University Named after Alexander and Nikolay Stoletovs, Gorky Str. 87, 600000 Vladimir, Russia

* Correspondence: eprusov@mail.ru; Tel.: +7-4922-479-821

Received: 7 May 2018; Accepted: 6 June 2018; Published: 9 June 2018

\begin{abstract}
This paper deals with the investigation of complex-alloyed nickel aluminides obtained from oxide compounds by aluminothermic reduction. The aim of the work was to study and develop the physicochemical basis for obtaining complex-alloyed nickel aluminides and their application for enhancing the properties of coatings made by electrospark deposition (ESD) on steel castings, as well as their use as grain refiners for tin bronze. The peculiarities of microstructure formation of master alloys based on the Al-TM (transition metal) system were studied using optical, electronic scanning microscopy and $\mathrm{X}$-ray spectral microanalysis. There were regularities found in the formation of structural components of aluminum alloys (Ni-Al, Ni-Al-Cr, Ni-Al-Mo, Ni-Al-W, Ni-Al-Ti, $\mathrm{Ni}-\mathrm{Cr}-\mathrm{Mo}-\mathrm{W}, \mathrm{Ni}-\mathrm{Al}-\mathrm{Cr}-\mathrm{Mo}-\mathrm{W}-\mathrm{Ti}, \mathrm{Ni}-\mathrm{Al}-\mathrm{Cr}-\mathrm{V}$, Ni-Al-Cr-V-Mo) and changes in their microhardness, depending on the composition of the charge, which consisted of oxide compounds, and on the amount of reducing agent (aluminum powder). It is shown that all the alloys obtained are formed on the basis of the $\beta$ phase (solid solution of alloying elements in nickel aluminide) and quasi-eutectic, consisting of the $\beta^{\prime}$ phase and intermetallics of the alloying elements. The most effective alloys, in terms of increasing microhardness, were Al-Ni-Cr-Mo-W (7007 MPa) and Al-Ni-Cr-V-Mo (7914 MPa). The perspective is shown for applying the synthesized intermetallic master alloys as anode materials for producing coatings by electrospark deposition on steel of C1030 grade. The obtained coatings increase the heat resistance of steel samples by 7.5 times, while the coating from NiAl-Cr-Mo-W alloy remains practically nonoxidized under the selected test conditions. The use of $\mathrm{NiAl}$ intermetallics as a modifying additive $(0.15 \mathrm{wt}$. \%) in tin bronze allows increasing the microhardness of the $\alpha$-solid solution by 1.9 times and the microhardness of the eutectic ( $\alpha+\beta$ phase) by 2.7 times.
\end{abstract}

Keywords: intermetallic compounds; aluminothermic reduction; alloying elements; microhardness; microstructure; solid solutions; quasi-eutectic; electrospark deposition 


\section{Introduction}

Alloys with refractory metals, such as $\mathrm{W}, \mathrm{Mo}, \mathrm{Cr}, \mathrm{V}, \mathrm{Zr}$, etc., play an essential role in forming physical and mechanical properties of high-quality Al-Ni-based alloys. Having an increased resistance to oxidation at a temperature of $1000^{\circ} \mathrm{C}$, such alloys promise to be materials with a wide use in various engineering fields [1-3].

According to the $\mathrm{Ni}-\mathrm{Al}$ state diagram, two thermodynamically stable aluminides- $\mathrm{Ni}_{3} \mathrm{Al}$ and $\mathrm{NiAl}$ - are formed, which are in an equilibrium state with metals of group VIB: W (f14d4s2), Cr and Mo (d5s1), having occupied the intermediate position between electropositive (Al) and electronegative (Ni) metals in the ternary systems Al-Ni-X (transition metals). Their initial melting point is higher than that of Ni-Al alloys [4]. The most effective way to control the structure of aluminum (nickel) alloys is to introduce small amounts of transition metals (TM) as additions to binary [5-10] and multicomponent [11-19] master alloys: Al-TM (Ti, Zr, Sc, Hf, etc.) and Al-Sc-Zr; Al-Zr-Ti; Al-Sc-Ti; etc.

Currently, the problem of obtaining aluminides and their alloys has been solved by the traditional foundry technologies and powder metallurgy, which do not fully meet modern requirements. The proposed approach makes it possible to obtain complex nickel aluminides by means of a joint aluminothermic reduction of metal oxides [20]. It significantly simplifies the technology and reduces the production cost of new high-temperature, heat-resistant materials, which are intended for power engineering, aviation and automotive industries. At present, there is desire to improve the existing materials and create new refractory, heat-resistant and wear-resistant ones.

In most cases, it is not necessary to make parts entirely from these materials, as it is sufficient to obtain a functional coating with appropriate properties on the surface. The use of intermetallic alloys as materials for obtaining heat-resistant coatings is a promising trend now, electrospark deposition (ESD) being one of the modern technologies in this aspect. ESD is based on the electro-erosion process arising between the two electrodes - cathode (part) and anode (coating material) [21,22]. The main advantage of the ESD technology is that it allows forming high adhesion bonds between the cathode and anode material at the "coating-part" boundary, due to the appearance of a mixing zone there. This is a positive factor when a detail operates under heating-cooling conditions, where the cathode (steel) undergoes polymorphic transformation, which facilitates the coating peeling from the part surface.

Another application area of complex intermetallic compounds is their use as master alloys in nonferrous alloys, for example, in tin bronzes. Nowadays, the task of development of new master alloy compositions for the use as modifying additives is of current interest. The modifying effect is usually achieved by adding modifier, not exceeding $0.3 \mathrm{wt} . \%$, that helps to maintain proportions of the branded composition.

The aim of this work is to study and develop the physicochemical basis for the production of complex-alloyed nickel aluminides and the technologies for their application as grain refiners in tin bronze, and to enhance the properties of coatings made by electric spark deposition on steel castings.

\section{Materials and Methods}

The initial materials were powders (50-100 $\mu \mathrm{m}$ in size and 98.5-99 wt. \% purity) of oxides: NiO, $\mathrm{Cr}_{2} \mathrm{O}_{3}, \mathrm{MoO}_{3}, \mathrm{WO}_{3}, \mathrm{TiO}_{2} ; \mathrm{Al}$ powder (50 $\mu \mathrm{m}$ in size and $99.5 \mathrm{wt}$ \% purity); $\mathrm{CaF}_{2}(50 \mu \mathrm{m})$.

Metallothermic melting was carried out in refractory metal crucibles lined with a refractory material. The charge was prepared by mixing the components for 15-20 min, at $500 \mathrm{rpm}$ in an activator-type mixer made in the form of a sealed container of $0.5 \mathrm{~L}$. A periclase-chrome lining material $\left(\mathrm{MgOCr}_{2} \mathrm{O}_{3}\right)$ was used for making the crucibles' lining. The experiment was conducted in an air atmosphere. The charge was ignited in the bulk state, after vibration compaction at $100 \mathrm{~Hz}$ for $20 \mathrm{~min}$. The reaction was initiated by the electro-ignition from above. Then, the reaction proceeded without external heating. Oxidation and matter removal was small, so it was not taken into account. As a result of melting, two layers of products were obtained in the form of a metal and an oxide phase.

The method of obtaining alloys used in the work is well known as a variant of self-propagating high-temperature synthesis (SHS) [23,24]. In our case, the process was accompanied by the formation 
of a liquid phase, unlike the traditional SHS, where the process occurs in solid phase $[25,26]$. One of the disadvantages of the products obtained by the SHS method is its porosity, which makes it impossible to study the mechanical properties, but it does not hinder investigation of microhardness. The microhardness was measured by the conventional Vickers method using a microhardness tester PMT 3 at a load of $0.098 \mathrm{~N}$ (HV10), all values being in MPa used throughout the work. The arithmetic average of the obtained values of microhardness were calculated according to at least 10 measurements for each series of experiments.

The following research methods and equipment were used for structural characterization:

- $\quad$ X-ray spectral microanalysis was performed on the alloy complexes to determine the content of elements in different structural components using field emission scanning electron microscope (FE-SEM) Hitachi SU-70 (Tokyo, Japan) with attachments for energy-dispersive (Thermo Scientific Ultra Dry) and wave (Thermo Scientific Magna Ray) X-ray spectral microanalyzer;

- X-ray diffraction analysis, which was performed on a diffractometer "DRON-7" in copper radiation using a diffraction database.

The alloy porosity is not considered to be an obstacle for using it as a master alloy or as an electrode material for making coatings by ESD. Coatings were obtained using a factory-built electric spark unit, Elitron 22A. Steel samples of C1030 grade with identical surface areas $\left(1.5 \mathrm{~cm}^{2}\right)$ were used as cathodes.

To be sure that the obtained intermetallic alloys are applicable in ESD technology and, if they are, to determine the optimum time for electro spark treatment, the curves of kinetic dependence of the cathodes' mass changes (mass transfer) were made using the gravimetric method by weighing the electrodes on the AW 220 analytical scale every minute of treatment. Heat resistance of the obtained coatings was studied using a Q-1000 derivatograph; kinetic studies were performed at atmospheric pressure in air medium at a heating rate of $10^{\circ} \mathrm{C} / \mathrm{min}$ up to $900{ }^{\circ} \mathrm{C}$, followed by an hour of exposure and cooling.

\section{Results and Discussion}

The conditions for obtaining nickel aluminides and their doping with refractory metals ( $\mathrm{W}, \mathrm{Mo}, \mathrm{Cr}$, $\mathrm{V}, \mathrm{Ti}$ ) have been considered previously in papers $[25,26]$. The process of obtaining alloys is represented by a series of partial reactions of aluminothermic reduction and is described generally by the chemical reaction equation: $\mathrm{M}_{n} \mathrm{O}_{m}+p \mathrm{Al}=n \mathrm{M}+\mathrm{Al}_{p} \mathrm{O}_{m}$, where $\mathrm{M}_{n} \mathrm{O}_{m}$ is a reducible metal oxide, Al—a reducer, $n \mathrm{M}$-a reduced metal, $\mathrm{Al}_{p} \mathrm{O}_{m}$ - a compound formed in the reaction; $n, m, p$-stoichiometric coefficients. The predominant reaction in the process of nickel oxide reduction proceeds according to the scheme $3 \mathrm{NiO}+2 \mathrm{Al}=3 \mathrm{Ni}+\mathrm{Al}_{2} \mathrm{O}_{3}$. This reaction is highly exothermic [27]. The reduction of metal oxides by aluminum is characterized by differential thermal analysis (DTA). It has been found that the oxide reduction process enters the active phase after the melting of aluminum at $660{ }^{\circ} \mathrm{C}$ and continues under a heterogeneous mechanism in the temperature range of $750-900{ }^{\circ} \mathrm{C}$. For example, thermal transformations in the $\mathrm{NiO}-\mathrm{Al}$ system are described by an exothermic effect at $884{ }^{\circ} \mathrm{C}$, corresponding to the onset of nickel reduction.

For a successful metallothermic synthesis of NiAl intermetallics, it is necessary to provide a certain thermal effect sufficient for the charge melting and the formation of an intermetallic compound. In aluminothermic systems, including in the $\mathrm{NiO}-\mathrm{Al}$ system, the real temperature reaches $2500{ }^{\circ} \mathrm{C}$. This is significantly higher than the melting point of $\mathrm{NiAl}\left(1638^{\circ} \mathrm{C}\right)$ and the required temperature for the synthesis of the intermetallic compound. Aluminum was taken with an excess as compared to the calculated amount. The excess of aluminum, which does not participate in the reduction reaction, passes into the metallic phase, forming nickel aluminide. When the ratio $\mathrm{NiO}: \mathrm{Al}$ changes from 1:0.45 to 1:0.65 mass fractions, the following composition of the $\mathrm{NiAl}$ alloy is formed, atom \%: $49.37 \mathrm{Ni}$ and $50.63 \mathrm{Al}$; the average microhardness is $5484 \mathrm{MPa}$, and the alloy yield is $70-90 \%$. 
The content of aluminum as a reducing agent varies from 0.45 to 0.65 , and the content of $\mathrm{CaF}_{2}$ as the ballast additive from 0.2 to 0.7 mass fractions. $\mathrm{CaF}_{2}$ additives increase the slag fluidity thus facilitating the formation of the ingot and, at the same time, reducing the temperature of the process by preventing the splash of metal from the crucible. The oxide content of chromium $(\mathrm{Cr})$, molybdenum (Mo), tungsten (W), titanium (Ti) varies from 0.1 to 0.3 mass fractions. The microstructure investigation of the obtained alloys on the scanning electron microscope in the X-ray mode showed that the alloys consist of a $\beta^{\prime}$ phase with the alloying elements dissolved in it (dark gray areas) and quasi-eutectic (light gray areas). For example, $\beta^{\prime}+\left(\mathrm{MoNi}\right.$; $\mathrm{AlMo}_{3}$; etc.) (Figure 1$)$.

The character of the elemental distribution in various structural components of the alloys Ni-Al-X $(\mathrm{X}=\mathrm{Mo}, \mathrm{W}, \mathrm{Cr}, \mathrm{Ti})$ was studied. Figure 1a-d shows the places of element analysis in different structural components-solid solution based on nickel aluminide $\mathrm{NiAl}$ and the eutectic containing molybdenum, tungsten, chromium and titanium.

\subsection{Alloy No. 1. Ni-Al-Mo}

Figure 1a shows the distribution of elements in various structural components of the alloy:

- In $\beta^{\prime}$-solid solution based on $\mathrm{NiAl}$ (points 3-5 on Figure 1a), the following elements are dissolved, atom \%: $61.35 \mathrm{Ni} ; 38.04 \mathrm{Al} ; \beta^{\prime}=\mathrm{Ni}_{61.35} \mathrm{Al}_{38.04}=\mathrm{Ni}_{1,6} \mathrm{Al}$. In this phase, 0.24 atom \% Mo is dissolved;

- In the quasi-eutectic (points 1, 2, 6 on Figure 1a) the content of $\mathrm{Ni}$ and $\mathrm{Al}$ decreases, and the concentration of Mo increased substantially in comparison with the $\beta^{\prime}$ phase, atom \%: $58.64 \mathrm{Ni}$; 3.65 Al; 37.69 Mo. It can be assumed that the intermetallide phase $\mathrm{MoNi}\left(\beta^{\prime}+\mathrm{MoNi}\right)$ crystallizes in quasi-eutectic.

This alloy has the following chemical composition, atom \%: $63.33 \mathrm{Ni} ; 30.69 \mathrm{Al} ; 5.97 \mathrm{Mo}$; and microhardness $5144 \mathrm{MPa}$.

\subsection{Alloy No. 2. Ni-Al-W}

Figure $1 \mathrm{~b}$ shows the points for analysis of the elements in the structural constituents of the alloy:

- In $\beta^{\prime}$ phase of the variable composition (points 4-6 on Figure $1 b$ ), 65.22 atom $\% \mathrm{Ni}$ and 34.44 atom \% $\mathrm{Al}$ are dissolved, but $\mathrm{W}$ is not dissolved in this phase; $\beta^{\prime}=\mathrm{Ni}_{65.22} \mathrm{Al}_{34.44}=\mathrm{Ni}_{1,9} \mathrm{Al}$;

- In quasi-eutectic (points 1-3 on Figure $1 \mathrm{~b}$ ), 12.81 atom $\% \mathrm{Ni}$ and 87.18 atom $\% \mathrm{~W}$ are dissolved, but $\mathrm{Al}$ does not dissolve in this phase; $\mathrm{W}$ is in the form of a rounded, independent phase in the eutectic, since Ni does not dissolve in $\mathrm{W}$.

This alloy has the following chemical composition, atom \%: $62.95 \mathrm{Ni} ; 33.86 \mathrm{Al} ; 3.19 \mathrm{~W}$; and microhardness $6226 \mathrm{MPa}$.

\subsection{Alloy No. 3. Ni-Al-Cr}

Figure 1c shows points for analysis of the structural constituents of the alloy elements:

- $\quad$ In $\beta^{\prime}$ phase (points 1-3, 7-10 on Figure 1c), the dissolved elements are, atom \%: $51.08 \mathrm{Ni}$; $43.32 \mathrm{Al}$; $5.58 \mathrm{Cr} ; \beta^{\prime}=\mathrm{Ni}_{51.08} \mathrm{Al}_{3.32}=\mathrm{Ni}_{1.18} \mathrm{Al}$ with 5.58 atom \% Cr;

- In quasi-eutectic (points 4-6 on Figure 1c), the dissolved elements are, atom \%: $17.7 \mathrm{Ni} ; 5.35 \mathrm{Al}$; $76.93 \mathrm{Cr}$. The assumed $\beta^{\prime}$ phase of the variable composition has the corresponding stoichiometric ratio, atom $\%: \beta^{\prime}=\mathrm{Ni}_{51.08} \mathrm{Al}_{43.32}=\mathrm{Ni}_{1.18} \mathrm{Al} ; 5.58$ atom $\% \mathrm{Cr}$ is dissolved in nickel aluminide;

- In eutectic (points 4, 5, 6), the dissolved elements are, atom \%: $17.7 \mathrm{Ni} ; 5.35 \mathrm{Al} ; 76.93 \mathrm{Cr}$. According to the phase diagrams of the alloys $\mathrm{Ni}-\mathrm{Cr}$ and $\mathrm{Al}-\mathrm{Cr}$, nickel and aluminum can be dissolved in chromium, thus forming a $\beta$-solid solution based on chromium.

This alloy has the following chemical composition, atom \%: $37.29 \mathrm{Ni}$; $2.62 \mathrm{Al}$; $9.9 \mathrm{Cr}$; and microhardness $4672 \mathrm{MPa}$. 


\subsection{Alloy No. 4. Ni-Al-Ti}

Figure $1 \mathrm{~d}$ shows the analysis of elements in the structural constituents of the alloy, atom \%:

- $\quad$ In $\beta^{\prime}$ phase (Figure 1d, points 1-3), the following elements are dissolved, atom \%: $52.33 \mathrm{Ni}$; 41.35 Al; $6.31 \mathrm{Ti} ; \beta^{\prime}=\mathrm{Ni}_{52.33} \mathrm{Al}_{41.35}=\mathrm{Ni}_{1.27} \mathrm{Al}$ with 6.31 atom \% Ti; at the points $4-5$, the mixture of nickel aluminide and titanium aluminide is formed, atom \%: $29.06 \mathrm{Ni} ; 35.75 \mathrm{Al} ; 35.23 \mathrm{Ti}$;

- In quasi-eutectic (Figure 1d, points 6-9), $\mathrm{Ni}$ and $\mathrm{Al}$ content decreased, and $\mathrm{Ti}$ concentration increased substantially in comparison with the $\beta^{\prime}$ phase, atom \%: $33.84 \mathrm{Ni} ; 36.07 \mathrm{Al} ; 30.08 \mathrm{Ti}$. Therefore, intermetallides, nickel aluminides and titanium nickelides may be the second phases in the eutectic.

This alloy has the following chemical composition, atom \%: $49.61 \mathrm{Ni}$; $40.34 \mathrm{Al}$; $10.05 \mathrm{Ti}$; and microhardness $6908 \mathrm{MPa}$.

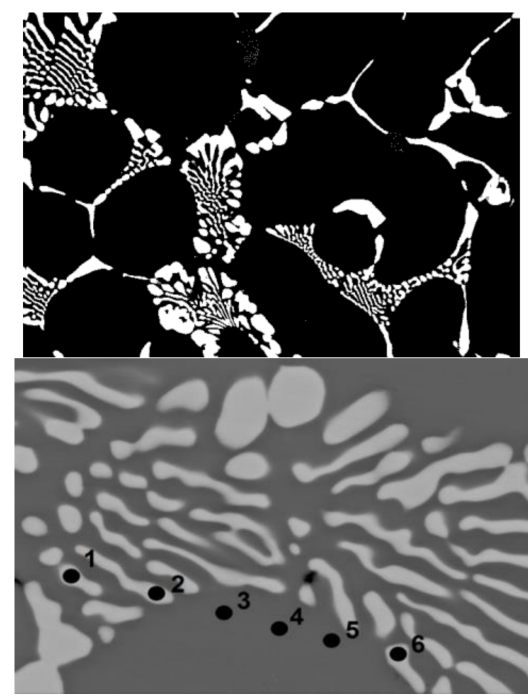

Alloy Ni-Al-Mo (a)
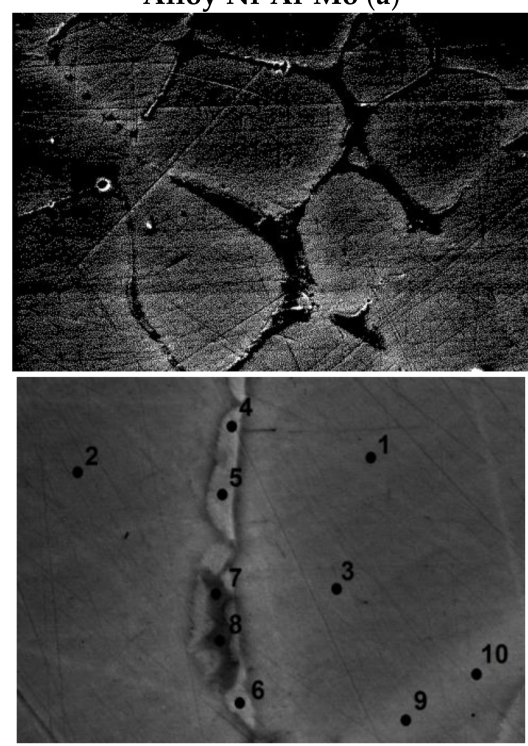

Alloy Ni-Al-Cr (c)
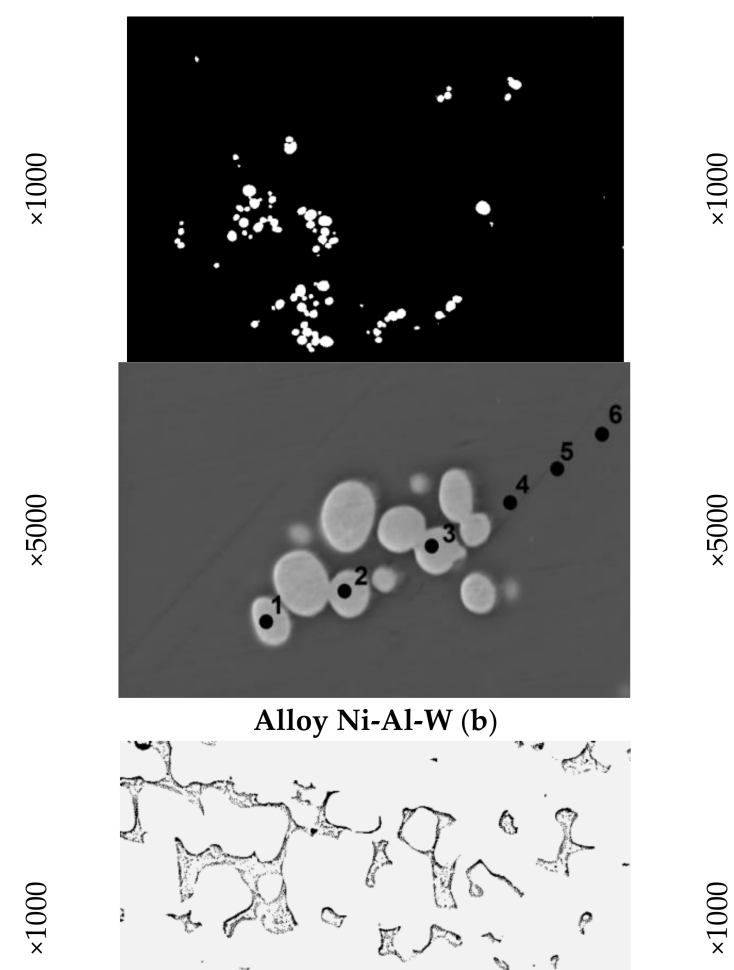

$\frac{8}{8}$

8
8
$\stackrel{8}{x}$
×

Figure 1. Microstructure and points of the analysis of structural elements constituents of Ni-Al-X system: (a) Ni-Al-Mo alloys; (b) Ni-Al-W; (c) Ni-Al-Cr; (d) Ni-Al-Ti. 
Thus, nickel aluminides (NiAl) doped with chromium, molybdenum, tungsten, and titanium have been obtained in the process of aluminothermic reduction of metal oxides. The compositions of the initial charge have been established, and the basic conditions for obtaining alloys have been determined. The results of thermodynamic evaluation and thermal analysis of aluminothermic systems confirm the high probability of thermodynamic reduction of metal oxides in the range of $800-1000{ }^{\circ} \mathrm{C}$ and are consistent with the experimental data. The alloys obtained are identified, according to the results of element-phase and X-ray diffraction analyses, as nickel aluminides containing chromium, molybdenum, tungsten, titanium (1.5-6.5 wt. \%), and quasi-eutectics.

\subsection{Alloys No. 5. Ni-Al-Cr-Mo-W and No. 6. Ni-Al-Cr-Mo-W-Ti}

Analysis of Table 1 shows that with an increase in the aluminum additive from 0.5 to 0.6 mass fractions, the content of $\mathrm{W}$ and Mo decreases but the concentration of $\mathrm{Cr}$ and Ni increases, however, the microhardness of the alloy increases from $6200 \mathrm{MPa}$ to $7436 \mathrm{MPa}$. With an increase in the addition of $\mathrm{CaF}_{2}$ flux from 0.5 to 0.65 of mass fractions, an increase in the content of $\mathrm{Ti}, \mathrm{Mo}, \mathrm{Cr}$ and a decrease in the concentration of $\mathrm{W}, \mathrm{Al}$ and $\mathrm{Ni}$ is observed, and the microhardness of the alloy increases from $5584 \mathrm{MPa}$ to $6908 \mathrm{MPa}$.

Thus, the change in the amounts of aluminum and flux additives $\mathrm{CaF}_{2}$ in this way affects the content of alloying elements in the synthesized alloys, as well as having an effect on their microhardness.

Figure 2a shows the microstructure of the Ni-Al-Cr-Mo-W alloy (Table 1, No. 5.2) containing four structural components: matrix of the $\beta^{\prime}$ phase of a solid substitute solution based on NiAl (point 1 , dark gray part) and inclusions of $\mathrm{W}$ (point 2), Mo (point 3) and $\mathrm{Cr}$ (point 4). In $\beta^{\prime}$ phase (point 1) they are dissolved, atom \%: $55.69 \mathrm{Ni} ; 39.1 \mathrm{Al} ; 5.21 \mathrm{Cr}$ : $\mathrm{Ni}_{55.69} \mathrm{Al}_{39.1} \mathrm{Cr}_{5.21}=\mathrm{Ni}_{10.69} \mathrm{Al}_{7.5} \mathrm{Cr}=\mathrm{Ni}_{10.69}(\mathrm{Al}, \mathrm{Cr})_{8.5}$ $=\mathrm{Ni}(\mathrm{Al}, \mathrm{Cr})_{1.26}$.

Table 1. Charge composition, elemental content and microhardness of alloys No. 5 and No. 6.

\begin{tabular}{|c|c|c|c|c|c|c|c|c|c|c|c|c|c|c|}
\hline \multirow{2}{*}{ No. } & \multicolumn{7}{|c|}{ Charge Composition Ratio, Weight Fractions } & \multicolumn{6}{|c|}{ Elements Content, atom \% } & \multirow{2}{*}{$\begin{array}{c}\text { Microhardness, } \\
\text { MPa }\end{array}$} \\
\hline & $\mathrm{NiO}$ & $\mathrm{Cr}_{2} \mathrm{O}_{3}$ & $\mathrm{MoO}_{3}$ & $\mathrm{WO}_{3}$ & $\mathrm{TiO}_{2}$ & Al & $\mathrm{CaF}_{2}$ & $\mathrm{Ni}$ & Al & $\mathrm{Cr}$ & Mo & W & $\mathrm{Ti}$ & \\
\hline 5. & \multicolumn{13}{|c|}{ Alloy Ni-Al-Cr-Mo-W } & \\
\hline 5.1. & 1 & 0.14 & 0.14 & 0,14 & - & 0.5 & 0.65 & 36.54 & 20.85 & 15.91 & 10.91 & 15.79 & - & 6200 \\
\hline 5.2 . & 1 & 0.14 & 0.14 & 0.14 & - & 0.6 & 0.65 & 37.95 & 20.67 & 16.59 & 10.32 & 14.47 & - & 7436 \\
\hline 6. & \multicolumn{13}{|c|}{ Alloy Ni-Al-Cr-Mo-W-Ti } & \\
\hline 6.1. & 1 & 0.14 & 0.14 & 0.14 & 0.14 & 0.5 & 0.5 & 38.00 & 25.02 & 8.22 & 5.43 & 8.78 & 14.55 & 5584 \\
\hline 6.2. & 1 & 0.14 & 0.14 & 0.14 & 0.14 & 0.5 & 0.65 & 37.00 & 24.42 & 9.16 & 5.71 & 8.3 & 15.41 & 6908 \\
\hline
\end{tabular}

In the light colored crystal (point 2) of the compact shape, the elements are concentrated as follows, atom \%: 65.8 W; $23.59 \mathrm{Mo} ; 5.87 \mathrm{Ni}$ and $4.75 \mathrm{Cr}$. Aluminum does not dissolve in this crystal: $\mathrm{W}_{65.8} \mathrm{Mo}_{23.59} \mathrm{Ni}_{5.87} \mathrm{Cr}_{4.75}=\mathrm{W}_{13.85} \mathrm{Mo}_{4.97} \mathrm{Ni}_{1.24} \mathrm{Cr}=\mathrm{W}_{13.85}(\mathrm{Mo}, \mathrm{Ni}, \mathrm{Cr})_{7.21}=\mathrm{W}_{1.92}(\mathrm{Mo}, \mathrm{Ni}, \mathrm{Cr}) \approx \mathrm{W}_{2}(\mathrm{Mo}$, $\mathrm{Ni}, \mathrm{Cr}$ ).

In darker colored crystals (points 3 and 4), the following elements are dissolved, atom \%: (26.34-36.69) Mo; (32.5-34.88) Ni; (15.79-28.85) Cr; (8.06-10.37) W; (4.65-4.87) Al. These points are likely to represent quasi-eutectic of the above-mentioned elements. The diffraction pattern of the $\mathrm{Ni}-\mathrm{Al}-\mathrm{Cr}-\mathrm{Mo}-\mathrm{W}$ alloy shows the presence of nickel aluminide and such alloying elements as $\mathrm{Cr}$, Mo and W. The formation of solid solutions of NiAl with $\mathrm{Cr}$, Mo and $\mathrm{W}$ is not excluded.

At further doping with titanium (Table 1, alloys No. 6.1 and 6.2) and additions of $\mathrm{CaF}_{2}$ flux 0.5-0.65 mass fractions, there is observed an increase of $\mathrm{Cr}$, Mo and Ti content, but a decrease of $\mathrm{Al}$ and $\mathrm{W}$ concentration. 


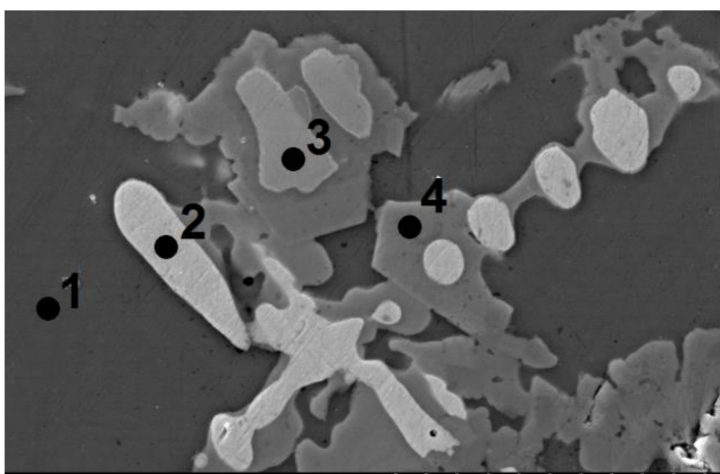

(a) $\times 2000$

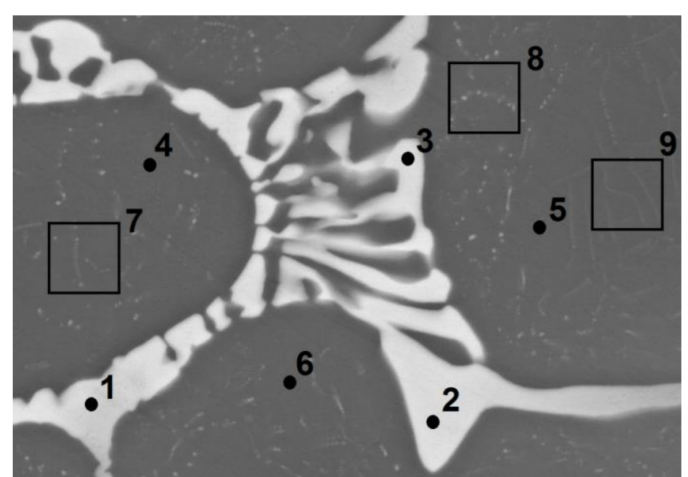

(b) $\times 5000$

Figure 2. Microstructure of (a) Ni-Al-Cr-Mo-W and (b) Ni-Al-Cr-Mo-V alloys and the points of analysis of elements structural components.

\subsection{Alloy No. 7. Ni-Al-Cr-V and Alloy No. 8. Ni-Al-Cr-Mo-V}

From Table 2, it follows that as the value of the aluminum additive increases from 0.5 to 0.65 mass fractions, when the additions of $\mathrm{NiO}, \mathrm{Cr}_{2} \mathrm{O}_{3}, \mathrm{~V}_{2} \mathrm{O}_{3}$ and flux of $\mathrm{CaF}_{2}$ are constant, there is a tendency toward decreasing $\mathrm{V}$ content and increasing the concentration of $\mathrm{Ni}$ and $\mathrm{Cr}$ in alloys No. 7.1-7.3. The $\mathrm{Al}$ content remains practically unchanged.

In Ni-Al-Cr-Mo-V alloys (alloys No. 8.1 and 8.2, Table 2), the increase in the $\mathrm{CaF}_{2}$ flux from 0.5 to 0.6 mass fractions leads to a content increase of $\mathrm{Ni}, \mathrm{Al}$ and Mo but, at the same time, a concentration decrease of $\mathrm{V}$ and $\mathrm{Cr}$.

The local element composition analysis of the structural components of the Ni-Al-Cr-Mo-V alloy showed that:

In $\beta^{\prime}$ phase (points 4-9 in Figure 2b), the following elements are dissolved, atom \%: $50.35 \mathrm{Ni}$; $41.57 \mathrm{Al} ; 4.67 \mathrm{Cr} ; 0.53 \mathrm{Mo} ; 2.87 \mathrm{~V} ; \mathrm{Ni}_{50.35} \mathrm{Al}_{41.57}=\mathrm{Ni}_{1.21} \mathrm{Al}$ with alloying elements $\mathrm{Cr}$, Mo and $\mathrm{V}$;

- In quasi-eutectic (points 1-3 on Figure 2b), the following elements are dissolved, atom \%: $10.2 \mathrm{Ni}$; $5.88 \mathrm{Al} ; 31.94 \mathrm{Cr} ; 32.68 \mathrm{Mo} ; 19.28 \mathrm{~V}$. According to the phase diagram of $\mathrm{V}-\mathrm{Cr}$, these elements form continuous solid solutions.

Table 2. Charge composition and elements content in alloys No. 7 and No. 8.

\begin{tabular}{|c|c|c|c|c|c|c|c|c|c|c|c|}
\hline \multirow{2}{*}{ No. } & \multicolumn{6}{|c|}{ Charge Composition Ratio, Weight Fractions } & \multicolumn{5}{|c|}{ Elements Content, atom \% } \\
\hline & $\mathrm{NiO}$ & $\mathrm{Cr}_{2} \mathrm{O}_{3}$ & $\mathrm{~V}_{2} \mathrm{O}_{3}$ & $\mathrm{MoO}_{3}$ & Al & $\mathrm{CaF}_{2}$ & $\mathrm{Ni}$ & Al & $\mathrm{Cr}$ & $\mathbf{V}$ & Mo \\
\hline 7. & \multicolumn{11}{|c|}{ Alloy Ni-Al-Cr-V } \\
\hline 7.1. & 1 & 0.14 & 0.14 & - & 0.5 & 0.65 & 43.82 & 34.21 & 13.28 & 8.69 & - \\
\hline 7.2 . & 1 & 0.14 & 0.14 & - & 0.6 & 0.65 & 44.36 & 34.84 & 13.24 & 7.56 & - \\
\hline 7.3. & 1 & 0.14 & 0.14 & - & 0.65 & 0.65 & 45.11 & 34.09 & 13.41 & 7.39 & - \\
\hline 8. & \multicolumn{11}{|c|}{ Alloy Ni-Al-Cr-Mo-V } \\
\hline 8.1. & 1 & 0.14 & 0.14 & 0.14 & 0.65 & 0.5 & 35.43 & 29.36 & 10.42 & 11.34 & 13.45 \\
\hline 8.2. & 1 & 0.14 & 0.14 & 0.14 & 0.65 & 0.65 & 35.77 & 29.50 & 10.22 & 10.48 & 14.03 \\
\hline
\end{tabular}

Thus, with the compositions of the selected reductant (0.5-0.6 Al mass fractions), flux (0.3-0.6 $\mathrm{CaF}_{2}$ mass fractions) and reduced oxides of $\mathrm{Mo}, \mathrm{W}, \mathrm{Cr}, \mathrm{Ti}$ (0.1-0.3 mass fractions), the average content of the components in alloys varies within the following limits, atom \%:

- $\quad$ system Ni-Al-Mo: $63.33 \mathrm{Ni} ; 39.69 \mathrm{Al} ; 5.97 \mathrm{Mo}$;

- $\quad$ system Ni-Al-W: $62.95 \mathrm{Ni} ; 33.96 \mathrm{Al} ; 3.19 \mathrm{~W}$;

- $\quad$ system Ni-Al-Cr: $37.29 \mathrm{Ni} ; 32.81 \mathrm{Al} ; 29.90 \mathrm{Cr}$; 
- $\quad$ system Ni-Al-Ti: $49.61 \mathrm{Ni} ; 40.34 \mathrm{Al} ; 10.05 \mathrm{Ti}$.

The results of elemental-phase and X-ray diffraction analysis shows that the resulting alloys are formed on the basis of two structural components: $\mathrm{NiAl}$ with a variable content of alloying elements ( $\beta^{\prime}$ phase) and quasi-eutectic consisting of $\beta^{\prime}$ phase and intermetallide phases.

According to the degree of microhardness increase, the alloys should be arranged in the following order: Ni-Al-Cr $(4672 \mathrm{MPa}) \rightarrow \mathrm{Ni}-\mathrm{Al}-\mathrm{Mo}(5441 \mathrm{MPa}) \rightarrow \mathrm{Ni}-\mathrm{Al}(5484 \mathrm{MPa}) \rightarrow \mathrm{Ni}-\mathrm{Al}-\mathrm{W}(6226 \mathrm{MPa}) \rightarrow$ $\mathrm{Ni}-\mathrm{Al}-\mathrm{Cr}-\mathrm{Mo}-\mathrm{W}-\mathrm{Ti}(6246 \mathrm{MPa}) \rightarrow \mathrm{Ni}-\mathrm{Al}-\mathrm{Cr}-\mathrm{V}(6439 \mathrm{MPa}) \rightarrow \mathrm{Ni}-\mathrm{Al}-\mathrm{Ti}(6908 \mathrm{MPa}) \rightarrow \mathrm{Ni}-\mathrm{Al}-\mathrm{Cr}-\mathrm{Mo}-\mathrm{W}$ $(7007 \mathrm{MPa}) \rightarrow$ Ni-Al-Cr-V-Mo (7914 MPa).

The synthesized intermetallic alloys were used to form heat-resistant coatings on steel samples of C1030 grade, and also as master alloys for tin bronze. Coatings were obtained by the ESD method. Figure 3 shows dependences of the changes of the cathode mass values and the duration of treatment with intermetallic anode materials of different compositions. Dependences of other anode materials are not given due to the absence of mass transfer or intensive oxidation of the material, even when the ESD process was performed using an inert gas (argon blasting). As follows from the results obtained (Figure 3), the Ni-Al-Cr and Ni-Al-Cr-Mo-W alloys show the maximum mass transfer. In this case, the Ni-Al-W and Ni-Al-Mo alloys provide an increase in mass transfer for up to $360 \mathrm{~s}$ of treatment, and $\mathrm{Ni}-\mathrm{Al}-\mathrm{Cr}-\mathrm{Mo}-\mathrm{W}$ for $480 \mathrm{~s}$ of treatment. It should be noted that $\mathrm{Ni}-\mathrm{Al}$ and $\mathrm{Ni}-\mathrm{Al}-\mathrm{Cr}$ alloys in the chosen treatment intervals do not reach the starting point of the coating destruction, which is why the duration of the ESD process with these materials has been limited (600 s).

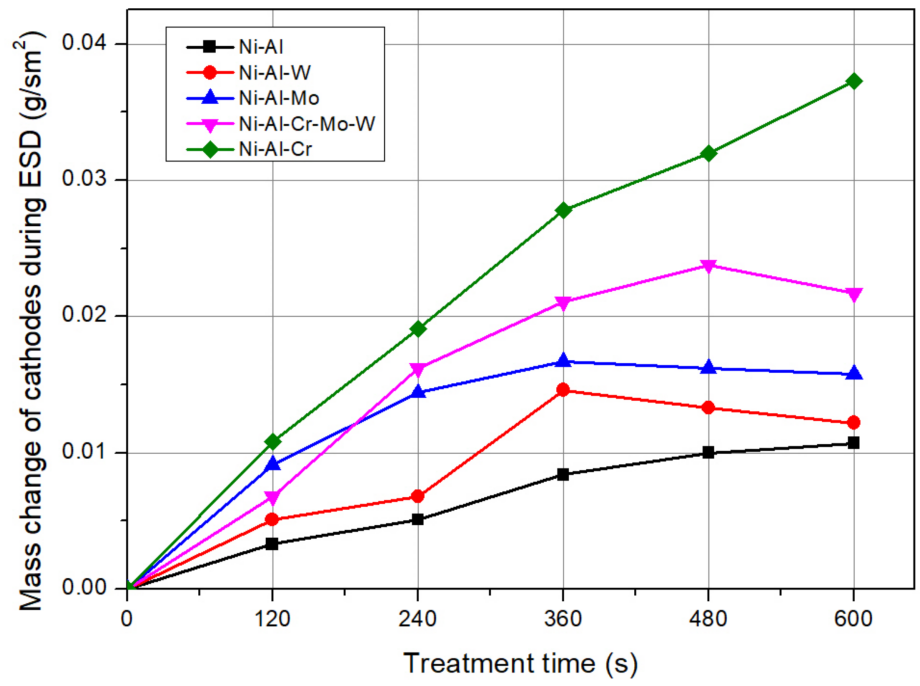

Figure 3. Mass change of steel cathodes during electric spark deposition by intermetallic anode materials.

Analyzing the character of the derivatographic curves, it was found that there are no abrupt changes in the mass of cathodes with coatings, in contrast to samples without coatings, after their heating above the temperature of polymorphous transformations. The microstructure investigation of the samples with coatings was carried out on thin sections made perpendicular to the coating. There are no swelling and detachment of coating from the base, which usually predetermines the diffusion mechanism of reducing the heat resistance. Based on the results of micro-X-ray spectral analysis, it can be stated that the general trend for the distribution of elements for all coatings is the decrease in the content of $\mathrm{Ni}, \mathrm{Al}, \mathrm{Cr}, \mathrm{Mo}, \mathrm{W}$ and the increase in the concentration of $\mathrm{Fe}, \mathrm{Mn}$ when approaching the substrate, which indicates the mixing of anode and cathode materials, causing adhesion.

Heat resistance for all coatings increased by about 7.5 times. By the degree of the heat resistance increase of the coatings, the alloys can be arranged as follows: Ni-Al-Cr, Ni-Al, Ni-Al-W, Ni-Al-Mo. The highest degree of heat resistance is provided by coating made with Ni-Al-Cr-Mo-W alloy, which practically does not oxidize in the time intervals under study, and thus could be recommended 
for practical application. Microstructure investigation of this coating has proved it to possess higher dispersion of structural components in comparison with other coatings, which helps to slow down the process of reactive diffusion.

Additional experiments were made to use nickel aluminides as grain refining additives in tin bronzes of CuSn6P grade. It was found that with the increase of the addition of nickel aluminide $(\mathrm{NiAl})$ to $0.15 \mathrm{wt}$. \% inclusive, the structural components of the tin bronze $\alpha$-solid solution and the eutectoid $(\alpha+\beta$ phase) are observed to be grinded and become coarse in microstructure to $0.25 \%$ that of the master alloy. With this addition of the master alloy, the maximum value of microhardness of the $\alpha$-solid solution is $1170 \mathrm{MPa}$, in the unmodified phase the microhardness is $600 \mathrm{MPa}$, in the eutectoid it is $1620 \mathrm{MPa}$, and in unmodified bronze it is $850 \mathrm{MPa}$.

\section{Conclusions}

(1) Nickel aluminides doped with chromium, molybdenum, tungsten, titanium and vanadium have been successfully obtained in the joint aluminothermic reduction of nickel oxide and transition metal oxides. The thermodynamic feasibility of joint reduction of oxides of alloying metals is consistent with the results of the experiments made on complex-alloyed nickel aluminides. Conditions for the alloys' synthesis have been studied and the obtained alloys have been identified by the methods of elemental and X-ray phase analysis. The microstructure investigations show that all the alloys obtained are formed on the basis of two structural components: nickel aluminide $(\mathrm{NiAl})$ with variable content of alloying elements ( $\beta^{\prime}$ phase) and quasi-eutectic consisting of $\beta^{\prime}$ phase and intermetallic phases.

(2) The obtained intermetallic alloys (Ni-Al, Ni-Al-Cr, Ni-Al-Mo, Ni-Al-W, Ni-Al-Cr-Mo-W) have been used as anode materials for the creation of heat-resistant coatings by the ESD method on steel C1030 grade, which actually display increased heat resistance by 7.5 times, while the $\mathrm{Ni}-\mathrm{Al}-\mathrm{Cr}-\mathrm{Mo}-\mathrm{W}$ alloy coating practically does not oxidize under the selected test conditions.

(3) The use of intermetallic NiAl as a modifying additive in tin bronze allows increase of the microhardness of the $\alpha$-solid solution by 1.9 times and the microhardness of the eutectoid $(\alpha+\beta$ phase) by 2.7 times, when adding of $0.15 \mathrm{wt}$. \% master alloy.

Author Contributions: V.G., H.R. and E.R. conceived and designed the study. E.K. and M.E. performed the experiments. E.R., S.K. and E.P. analyzed the data. H.R. and E.P. wrote the manuscript. V.D. guided this study, discussed the experimental results, and edited the manuscript. All authors contributed to discussions of the results, read and approved the manuscript.

Acknowledgments: The research was carried out using the equipment of the Center for Applied Materials Science of Pacific National University with financial support from the Ministry of Education and Science of the Russian Federation within the framework of the state orders (state registration number 11.7208.2017/7.8 and 11.3014.2017/4.6).

Conflicts of Interest: The authors declare no conflict of interest.

\section{References}

1. Bochenek, K.; Basista, M. Advances in processing of NiAl intermetallic alloys and composites for high temperature aerospace applications. Prog. Aerosp. Sci. 2015, 79, 136-146. [CrossRef]

2. Guo, J.; Wang, Z.; Sheng, L.; Zhou, L.; Yuan, C.; Chen, Z.; Song, L. Wear properties of NiAl based materials. Prog. Nat. Sci. 2012, 22, 414-425. [CrossRef]

3. Bhaskar, M.S. Quantitative phase field modelling of precipitate coarsening in Ni-Al-Mo alloys. Comp. Mat. Sci. 2018, 146, 102-111. [CrossRef]

4. Petzow, G.; Effenberg, G. (Eds.) Ternary Alloys: A Comprehensive Compendium of Results, Constitutional Data and Phase Diagrams; VCH: Weinheim, Germany; Basel, Switzerland; Cambridge, UK; New York, NY, USA, 1992; Volume 7.

5. Hyde, K.B.; Norman, A.F.; Prangnell, P.B. The Effect of Ti on Grain Refinement in Al-Sc Alloys. Mater. Sci. Forum 2002, 396-402, 39-44. [CrossRef] 
6. Song, M.; He, Y.; Fang, S. Effects of Zr Content on the Yield Strength of an Al-Sc Alloy. J. Mater. Eng. Perform. 2010, 20, 377-381. [CrossRef]

7. Dalen, M.E.; Dunand, D.C.; Seidman, D.N. Effects of Ti additions on the nanostructure and creep properties of precipitation-strengthened Al-Sc alloys. Acta Mater. 2005, 53, 4225-4235. [CrossRef]

8. Royset, J.; Ryum, N. Scandium in Aluminum Alloys. Int. Mater. Rev. 2005, 50, 19-44. [CrossRef]

9. Ghosh, G.; Asta, M. First-principles calculation of structural energetics of Al-TM (TM = Ti, Zr, Hf) intermetallics. Acta Mater. 2005, 53, 3225-3252. [CrossRef]

10. Marquis, E.A.; Seidman, D.N. Nanoscale structural evolution of $\mathrm{Al}_{3} \mathrm{Sc}$ precipitates in $\mathrm{Al}(\mathrm{Sc})$ alloys. Acta Mater. 2001, 49, 1909-1919. [CrossRef]

11. Fuller, C.B.; Murray, J.L.; Seidman, D.N. Temporal evolution of the nanostructure of Al(Sc,Zr) alloys: Part I-Chemical compositions of $\mathrm{Al}_{3}\left(\mathrm{Sc}_{1-\mathrm{x}} \mathrm{Zr}_{\mathrm{x}}\right)$ precipitates. Acta Mater. 2005, 53, 5401-5413. [CrossRef]

12. Knipling, K.E.; Karnesky, R.A.; Lee, C.P.; Dunand, D.C.; Seidman, D.N. Precipitation evolution in Al-0.1Sc, $\mathrm{Al}-0.1 \mathrm{Zr}$ and $\mathrm{Al}-0.1 \mathrm{Sc}-0.1 \mathrm{Zr}$ (at.\%) alloys during isochronal aging. Acta Mater. 2010, 58, 5184-5195. [CrossRef]

13. Zakharov, V.V. About alloying of aluminum alloys with transition metals. Met. Sci. Heat Treat. 2017, 59, 67-71. [CrossRef]

14. Malek, P.; Janecek, M.; Smola, B.; Bartuska, P.; Plestil, J. Structure and properties of rapidly solidified Al-Zr-Ti alloys. J. Mater. Sci. 2000, 35, 2625-2633. [CrossRef]

15. Popova, E.A.; Shubin, A.B.; Kotenkov, P.V.; Pastukhov, E.A.; Bodrova, L.E.; Fedorova, O.M. Al-Ti-Zr master alloys: Structure formation. Russ. Metall. (Met.) 2012, 5, 357-361. [CrossRef]

16. Popova, E.A.; Kotenkov, P.V.; Pastukhov, E.A.; Shubin, A.B. Master alloys Al-Sc-Zr, Al-Sc-Ti, and Al-Ti-Zr: Their manufacture, composition, and structure. Russ. Metall. (Met.) 2013, 8, 590-594. [CrossRef]

17. Popova, E.A.; Kotenkov, P.V.; Pastukhov, E.A. Synergetic effect in modifying with master alloys having an aluminide cubic structure. Russ. Metall. (Met.) 2016, 2, 189-193. [CrossRef]

18. Wang, X.; Chen, G.; Li, B.; Wu, L.; Jiang, D. Effects of Sc, Zr and Ti on the microstructure and properties of $\mathrm{Al}$ alloys with high Mg content. Rare Metals 2010, 29, 66-71. [CrossRef]

19. Xu, C.; Du, R.; Wang, X.; Hanada, S.; Yamagata, H.; Wang, W.; Ma, C. Effect of cooling rate on morphology of primary particles in Al-Sc-Zr master alloy. Trans. Nonferr. Met. Soc. China 2014, 24, 2420-2426. [CrossRef]

20. Lapshin, O.V.; Ovcharencko, V.E.; Boyangin, E.N. Thermokinetic and Thermo-physical Parameters of High-Temperature Synthesis of Intermetallide $\mathrm{Ni}_{3} \mathrm{Al}$ by Thermal Shock of a Powder Mixture of Pure Elements. Combust. Expl. Shock Waves 2002, 38, 430-434. [CrossRef]

21. Xie, Y.J.; Wang, M.C. Microstructural morphology of electrospark deposition layer of a high gamma prime superalloy. Surf. Coat. Technol. 2006, 201, 691-698. [CrossRef]

22. Reynold, J.L.; Holdren, L.R.; Brown, L.E. Electro-Spark Deposition. Adv. Mater. Process. 2003, 161, 35.

23. Oniashvili, G.S.H.; Aslamazashvili, Z.G.; Zakharov, G.V.; Tavadze, G.F.; Chikhradze, M.N.; Dzigrashvili, T.A.; Berner, A. SHS of fine-grained ceramics containing carbides, nitrides, and borides. Int. J. Self Propag. High Temp. Synth. 2013, 22, 185-188. [CrossRef]

24. Shekari, M.; Adeli, M.; Khobzi, A.; Kobashi, M.; Kanetake, N. Induction-activated self-propagating, high-temperature synthesis of nickel aluminide. Adv. Powder Technol. 2017, 28, 2974-2979. [CrossRef]

25. Gostishchev, V.V.; Astapov, I.A.; Medneva, A.V.; Ri, H.; Khimukhin, S.N. Fabrication of Alloyed Aluminum Nickelides by Metallothermy of Metals Oxides. Russ. J. Non-Ferr. Met. 2016, 57, 41-46. [CrossRef]

26. Gostishchev, V.V.; Astapov, I.A.; Seredyuk, A.V.; Khimukhin, S.N.; Ri, H. High-Temperature Synthesis of Composites Based on Nickel Aluminides. Inorg. Mater. 2016, 4, 419-422. [CrossRef]

27. Vrel, D.; Langlois, P.; Heian, E.M.; Karnatak, N.; Dubois, S.; Beaufort, M.-F. Reaction Kinetics and Phase Segregation in the $3 \mathrm{NiO}+2 \mathrm{Al} \rightarrow 3 \mathrm{Ni}+\mathrm{Al}_{2} \mathrm{O}_{3}$ Thermite System. Int. J. Self Propag. High Temp. Synth. 2003, 12, 261-270.

(c) 2018 by the authors. Licensee MDPI, Basel, Switzerland. This article is an open access article distributed under the terms and conditions of the Creative Commons Attribution (CC BY) license (http:/ / creativecommons.org/licenses/by/4.0/). 